\title{
Sources Of Variability In Global Equity Returns
}

Tulin Sener, SUNY-New Paltz, USA

Paul B. Girma, SUNY-New Paltz, USA

\begin{abstract}
This study examines basically major geographical sources of global returns and risks. The focus is on the relevance of global, regional and national allocation policies. Additionally, the significance of value-growth allocation policy is also analyzed. The empirical analysis covers major developed equity markets, and it is conducted within the framework of the international capital asset pricing model. Our findings show that although the global systematic risk is getting to be a fundamental determinant of global equity returns and risks, country and, particularly, region selection are still important. Global and regional risk together can explain at least two-thirds of the total variability of equity returns in the majority of developed markets. However, the results of this study indicate a trivial effect for the value-growth allocation policy.
\end{abstract}

Keywords: Global Equity Diversification, Equity Market Integration, and International Asset Pricing

\section{INTRODUCTION}

$\mathcal{G}$ is a fact that the global capital markets appear to be integrating gradually and more rapidly in developed markets, with growing global systematic risk. There is a concern that globalization and rising correlation risk will probably diminish the benefits of global equity diversification. On the other hand, region-and countryspecific shocks, barriers to international investing, and maturity level of markets limit the boundaries of the world market efficiency and integration. This will result in varying degrees of market segmentation that may enhance the benefits of global equity diversification and affect the country-specific equity valuation, as well as the global pricing. Globalization in financial markets goes on with its limitations and many studies concluded that the benefits of global equity diversification also continue (Goetzmann, et al. (2005), Stultz (2005), Hu (2006), Bekaert, et al. (2007), Sener (2008), and Naranjo and Porter (2009)). In this controversial and challenging environment, searching for the relative significance of the determinants of global equity returns and risks becomes a vitally important task.

Previous research defines the major global equity allocation policies in determining global equity returns and risks. These policies refer to: geographical (global, regional and national) allocation, industry allocation, value-growth allocation and size allocation. The relative importance of those allocation policies seem to be changing over time. Earlier studies have found that geographical allocation policies are superior to other allocation policies in determining the global equity returns (Heston and Rouwenhoust (1995), and Griffin and Karolyi (1998)). More recent works, from the late 1990s and early 2000s, have concluded the diminishing importance of geographical allocations and, particularly, the rising importance of industry effects (L'Her, et al. (2002), Wang, et al. (2003), and Dijk and Keijzer (2004)). The most recent works provide somewhat mixed results by implying the revival of geographical and, particularly regional, allocation policies (Campa and Fernandez (2006), Sener and Salavitabar (2004), Brooks and Del Negro (2005), Soriano and Climent (2006)).

Dijk and Keijzer (2004) measure that industry policy explains 30.7 percent of total variance, whereas regional allocation explains 15.5 percent. Size and value-growth allocations account for 5.4 and 4.5 percent of total variance, respectively. Soriano and Climent (2006) show a long-term and strong dominance of regional effects. Similarly, Vardharaj and Fabozzi (2007) indicate that the regional allocation policy explains about one-fourth of monthly or quarterly return variation for international funds. Further, Puchkov, et al. (2005) report the relative importance of country effects. Likewise, French (2008) explores a very strong negative link between host country 
equity market valuations and equity flows, which means that relative country-specific valuations are an important empirical determinant of international equity flows.

As for the controversial relative importance of the value-growth allocation, Sinquefield (1996) and Fama and French (1998) find evidence that value stocks tend to outperform growth stocks, not only in the US stock portfolios, but in the international portfolios as well. Qian, et al. (2009) assert that multi-strategy combinations in different market segments produce surprisingly low correlations and the value-growth investing delivers diversification. On the contrary, Pozen and Fleishman (2005) claim that the value-growth allocation policy is much less effective for the global equity diversification than for the US equity portfolios. Further, working with only US stocks, Phalippou (2008) states that the value premium is a little issue and it has less worth than it is often granted to it.

Some of the critical questions that arise now are: to what extent are some markets still geographically segmented and does regional and national selection matter? Another question is: what is the recent relative significance of the value-growth allocation? In this study, we address these issues and analyze how much variability of the global equity return is explained by the global, regional and national factors, as well as by the value-growth allocation policy. First, we determine and decompose the relative importance of the chosen determinants within the framework of the international capital asset pricing model (ICAPM). Then we measure the effects of equity allocation policies both as risk premiums and as risk fractions, by means of single-and multi-factor regression models for a sample of twelve major developed markets. To identify the explanatory power of the chosen allocation policies, we use the well-known concept of coefficient of determination, or $\mathrm{R}^{2}$. We show the increased importance of the global systematic risk in the determination of the global return and risk components. We observe the enhancement of integration in major developed markets, although the country and, particularly region, allocation policies are still important in some of those markets. We see that global and regional systematic risk together account for a substantial portion of the total variance of the global return. However, the contribution of the valuegrowth allocation is quite limited.

The remainder of this study is structured as follows: Following the introduction, Section 2 describes the decomposition analysis of the return and risk in regard to the allocation policies. Section 3 reports the sources of data and the estimation procedures. Section 4 presents the empirical evidence for the relative importance of the chosen allocation policies. To conclude, Section 5 summarizes our findings and draws conclusions.

\section{MODEL}

As it is well known, the most important conclusion derived from the CAPM is that the relevant risk is the systematic risk. This will hold true internationally if all international markets are fully efficient and purchasing power parity works perfectly, or if the representative investor cares only about the US dollar returns. ${ }^{1}$ International pricing states that the expected return on any asset (or country index) is basically determined by its covariance with the expected return on world market portfolio $\left(\mathrm{ER}_{\mathrm{w}}\right)$.

To measure the effects of the chosen allocation policies, depending on the ICAPM, here we refer to the security market line (SML) and the single index model (SIM). Based on the SML, the equilibrium country excess return $\left(E_{\mathrm{j}}-\mathrm{R}_{\mathrm{f}}\right)$ is expressed as:

$E R_{j}-R_{f}=b_{j w} *\left(E R_{w}-R_{f}\right)$

where $R_{f}$ refers to the risk-free rate. Beta coefficient $\left(b_{j w}\right.$ indicates the sensitivity of the country excess return to the global market volatility. It is calculated as:

$\mathrm{b}_{\mathrm{jw}}=\mathrm{Cov}_{\cdot \mathrm{jw}} / \operatorname{Var}_{\cdot \mathrm{w}}$. world return.

Here, $\mathrm{Cov}_{\text {.jw }}$ is the covariance between the country and world returns, while Var. $_{\mathrm{w}}$ is the variance of the

Further, we use the SIM to decompose the global market-specific and country-specific proportions of the 
country return. That is:

$R_{j}=a_{j}+b_{j w} * R_{w}+e_{j}$,

where $a_{j}$ and $b_{j w}$ are constants and $R_{j}, R_{w}$, and $e_{j}$ are stochastic. The terms $a_{j}$ and $b_{j w}$ can easily be estimated from a simple regression line. Similarly, the total risk of the country return $\left(\operatorname{Var}_{.}\right.$) can be divided into two components. That is:

$\operatorname{Var}_{. j}=b_{\mathrm{jw}}{ }^{2} * \operatorname{Var}_{. \mathrm{w}}+$ Var. ej,

where the first and second terms on the right side of Equation (4) denote respectively the global market-specific and country-specific (idiosyncratic or diversifiable ) risk components. ${ }^{2}$

Let us denote the global systematic risk fraction (GSRF) of the country return $\left(\mathrm{R}_{\mathrm{j}}^{2}\right)$, by dividing the global market-specific risk component into total risk, as follows:

$$
\mathrm{R}_{\mathrm{j}}^{2}=\mathrm{b}_{\mathrm{jw}}^{2} * \text { Var.w , Var. } \mathrm{j}
$$

In the SIM, the GSRF is equivalent to the coefficient of determination, or $\mathrm{R}^{2}$, the square of the correlation coefficient, which is used in common to measure the statistical significance of the explanatory power of the independent variable in regression analysis. The GSRF, or $\mathrm{R}^{2}$, tell us what fraction of a country's volatility is attributable to global market movements (common variance). It can be used as a proxy to measure the degree of market segmentation of a country with the world market. For example, the smaller values of the GSRF, or $\mathrm{R}^{2}$, imply higher degrees of segmentation, while the greater values indicate higher degrees of integration. In Equation (5), the GSFR, or $\mathrm{R}^{2}$, will fall between zero and one. Only, in the case of full integration, it will take a value of one.

Further, by adding regional and value-growth allocation policies as explanatory variables to Equation (1), in terms of excess returns, or risk premiums, we can derive the following multi-factor models.

$\mathrm{ER}_{\mathrm{j}}-\mathrm{R}_{\mathrm{f}}=\mathrm{b}_{\mathrm{jw}} *\left(\mathrm{ER}_{\mathrm{w}}-\mathrm{R}_{\mathrm{f}}\right)+\mathrm{b}_{\mathrm{r}} *\left(\mathrm{ER}_{\mathrm{r}}-\mathrm{R}_{\mathrm{f}}\right)$, and

$\mathrm{ER}_{\mathrm{j}}-\mathrm{R}_{\mathrm{f}}=\mathrm{b}_{\mathrm{jw}} *\left(\mathrm{ER}_{\mathrm{w}}-\mathrm{R}_{\mathrm{f}}\right)+\mathrm{b}_{\mathrm{r}} *\left(\mathrm{ER}_{\mathrm{r}}-\mathrm{R}_{\mathrm{f}}\right)++\mathrm{b}_{\mathrm{vg}} *\left(\mathrm{ER}_{\mathrm{vg}}-\mathrm{R}_{\mathrm{f}}\right)$.

Here $\mathrm{ER}_{\mathrm{r}}$ and $\mathrm{ER}_{\mathrm{vg}}$ refer to the expected returns of the regional and value-growth allocations, and $b_{\mathrm{r}}$ and $b_{\mathrm{vg}}$ represent the beta coefficients.

In the empirical SIM, the GSRF, or $\mathrm{R}^{2}$ measures the global market-specific risk component, while its difference from one reflects broadly the country-specific risk component. The difference between the $\mathrm{R}^{2} \mathrm{~s}$ of Equations (1) and (6) shows the explanatory power of the regional allocation, and the difference between the $\mathrm{R}^{2} \mathrm{~s}$ of Equations (6) and (7) indicates the contribution of the value-growth allocation policy.

\section{DATA AND ESTIMATION PROCEDURES}

A time series (long term) analysis of Equations (1), (6) and (7) for the excess returns of the country indices, over a period of 1989 through 2007, provides us important empirical evidence of the relative importance of global, regional and national allocation policies as well as the relevance of the value-growth allocation policy. Our empirical analysis includes thirty six regressions, comprised of one, two and three explanatory variables, as well as a correlation analysis for the region and country returns.

Country and region equity indices are obtained from the Standard and Poor's database. BMI World Index represents the world market and the country indices include large-cap stocks. To avoid the multicollinearity problem, the regional independent variable of the two-factor regression model is calculated as the difference of the monthly returns of the region and world indices. Likewise, the value-growth independent variable of the three-factor regression model is obtained as the value premium that is the difference between the returns on value and growth 
indices. Then, to obtain the monthly excess returns, the risk-free rate is deducted from the previously defined returns of the world, regions and countries.

Returns, in terms of U.S. dollars, are computed as logarithmic first differences in monthly country and region equity indices. Cross correlations and significance tests are calculated by using the XLSTAT. The annualized geometric mean returns, standard deviations and all regression models are obtained from Excel. Two-tailed t-tests are used for the significance of beta coefficients and Pearson correlations, while F-test is used for the significance of $\mathrm{R}^{2}$.

Table 1: Cross Correlations of Excess Dollar Returns for the Major Regions and Developed Countries (1989- 2007)

\begin{tabular}{|l|c|c|c|c|c|c|c|c|c|c|c|c|c|c|c|}
\hline \multicolumn{1}{|c}{$\begin{array}{c}\text { Region/ } \\
\text { Country }\end{array}$} & NA & EU & AP & AU & BE & CA & FR & GE & HK & IT & JP & NL & SW & UK & USA \\
\hline N. America & 1 & - & - & - & - & - & - & - & - & - & - & - & - & - & - \\
\hline Europe & 0.73 & 1 & - & & - & - & - & - & - & - & - & - & - & - & - \\
\hline Asia Pacific & 0.45 & 0.55 & 1 & - & - & - & - & - & - & - & - & - & - & - & - \\
\hline Australia & 0.57 & 0.63 & 0.55 & 1 & - & - & - & - & - & - & - & - & - & - & - \\
\hline Belgium & 0.57 & 0.81 & 0.38 & 0.46 & 1 & - & - & - & - & - & - & - & - & - & - \\
\hline Canada & 0.79 & 0.64 & 0.49 & 0.67 & 0.48 & 1 & - & - & - & - & - & - & - & - & - \\
\hline France & 0.66 & 0.91 & 0.48 & 0.53 & 0.79 & 0.58 & 1 & - & - & - & - & - & - & - & - \\
\hline Germany & 0.66 & 0.89 & 0.40 & 0.52 & 0.76 & 0.58 & 0.86 & 1 & - & - & - & - & - & - & - \\
\hline Hong Kong & 0.58 & 0.53 & 0.46 & 0.53 & 0.37 & 0.60 & 0.47 & 0.48 & 1 & - & - & - & - & - & - \\
\hline Italy & 0.45 & 0.65 & 0.38 & 0.38 & 0.55 & 0.47 & 0.61 & 0.62 & 0.32 & 1 & - & - & - & - & - \\
\hline Japan & 0.35 & 0.46 & 0.98 & 0.44 & 0.31 & 0.39 & 0.39 & 0.31 & 0.32 & 0.33 & 1 & - & - & - & - \\
\hline Netherlands & 0.70 & 0.91 & 0.49 & 0.58 & 0.83 & 0.60 & 0.85 & 0.85 & 0.50 & 0.57 & 0.40 & 1 & - & - & - \\
\hline Switzerland & 0.58 & 0.80 & 0.50 & 0.48 & 0.72 & 0.49 & 0.70 & 0.65 & 0.42 & 0.44 & 0.44 & 0.76 & 1 & - & - \\
\hline U.K. & 0.66 & 0.92 & 0.53 & 0.61 & 0.68 & 0.55 & 0.75 & 0.71 & 0.47 & 0.48 & 0.45 & 0.78 & 0.71 & 1 & - \\
\hline U.S.A. & 0.99 & 0.73 & 0.43 & 0.56 & 0.57 & 0.76 & 0.66 & 0.65 & 0.57 & 0.44 & 0.35 & 0.69 & 0.57 & 0.66 & 1 \\
\hline
\end{tabular}

Note: All correlation coefficients are statistically significant at $1 \%$ level

North America, Europe and Asia Pacific are the three major regions that have been chosen. For the study period, the market capitalizations for those regions are approximately 51, 33 and 16 percent, respectively. The sample includes twelve developed countries (Australia, Belgium, Canada, France, Germany, Hong Kong, Italy, Japan, Netherland, Switzerland, U.K., and U.S.A.). These largest developed markets account for about 93 percent of the world equity markets for the particular period. T. Bill rate (3-months) stands for the risk-free rate.

\section{EMPIRICAL FINDINGS}

Table 1 provides Pearson excess return correlations in terms of dollars by region and country breakdown for the period of 1989 through 2007. All Pearson correlations are significant at the 1 percent level. Majority of the cross correlations of the major developed countries are quite high, and mostly more than 50 percent, except Japan, Hong Kong and Italy. Regionally, North America seems to be more integrated with Europe rather than with Asia Pacific. The correlation coefficient is 73 percent for the former, and it is 45 percent for the latter.

Table 2 presents return and risk statistics and market shares for the particular period. We observe variability in excess returns, standard deviations and Sharpe ratios for the regions and countries, as well as for the returns of the value and growth indices. North America and Europe have about 6 percent average excess return with approximately 14 or 15 percent standard deviations, and with a Sharp ratio of 42 percent. On the contrary, Asia Pacific has minus 4.42 percent average excess return with a standard deviation of 21 percent, and with a minus Sharpe ratio of 21 percent. We see that the performance of Asia Pacific has been rather poor during recent two 
decades. Another feature is that the average excess return of the Value Index (5.8 percent) is greater than the average excess return of the Growth Index (3.4 percent) with a 2.4 percent difference. However, the annual standard deviations and the Sharpe ratios have mixed results. Additionally, as can be seen in Table 2, in regard to the market shares, North America and Europe together dominate the developed equity markets with a total share of 84 percent.

Tables 3A and 3B show the beta coefficients and the (adjusted) coefficients of determination, or $\mathrm{R}^{2} \mathrm{~s}$, for the single-and multi-factor regressions. F-tests of $\mathrm{R}^{2}$ for all regressions indicate strong statistical significance at 1 percent level. Similarly, all t-tests for the beta coefficients of the world index in the SIM and almost all the beta coefficients of the region index in the multiple factor models are statistically significant at 1 percent level, excluding Australia and Hong Kong. Most of the Durbin Watson statistics are around 2, indicating the lack of autocorrelation

Table 2: Excess Dollar Return and Risk Statistics for the Major Regions and Developed Countries (1989- 2007)

\begin{tabular}{|c|c|c|c|c|c|c|c|c|c|c|}
\hline \multirow[t]{2}{*}{$\begin{array}{l}\text { Region/ } \\
\text { Country }\end{array}$} & \multicolumn{3}{|c|}{$\begin{array}{c}\text { Market Index } \\
(\%)\end{array}$} & \multicolumn{3}{|c|}{$\begin{array}{c}\text { Value Index } \\
(\%)\end{array}$} & \multicolumn{3}{|c|}{$\begin{array}{c}\text { Growth Index } \\
(\%)\end{array}$} & \multirow[t]{2}{*}{$\begin{array}{c}\text { Market } \\
\text { Weight } \\
(\%)\end{array}$} \\
\hline & RT & S.D. & S.R. & RT & S.D. & S.R. & RT & S.D. & S.R. & \\
\hline N. America & 5.78 & 13.92 & 41.52 & - & - & - & - & - & - & 50.89 \\
\hline Europe & 6.44 & 15.12 & 42.58 & - & - & - & - & - & - & 33.10 \\
\hline Asia Pacific & -4.42 & 20.89 & -21.18 & - & - & - & - & - & - & 16.01 \\
\hline World & 4.28 & 13.81 & 30.99 & - & - & - & - & - & - & 100 \\
\hline Australia & 7.62 & 17.11 & 44.53 & 8.91 & 16.81 & 53.01 & 6.11 & 18.00 & 33.97 & 2.90 \\
\hline Belgium & 7.60 & 16.89 & 45.06 & 9.20 & 16.42 & 56.01 & 5.65 & 18.05 & 31.33 & 0.65 \\
\hline Canada & 3.92 & 17.39 & 22.53 & 4.52 & 16.15 & 28.01 & 2.71 & 19.56 & 18.83 & 3.93 \\
\hline France & 5.90 & 17.70 & 33.31 & 7.19 & 18.26 & 39.39 & 4.16 & 18.03 & 23.04 & 4.70 \\
\hline Germany & 4.46 & 21.02 & 21.21 & 6.18 & 20.16 & 30.65 & 2.34 & 22.64 & 10.34 & 3.72 \\
\hline Hong Kong & 7.27 & 25.61 & 28.39 & 8.85 & 25.46 & 34.78 & 5.15 & 26.75 & 19.26 & 0.94 \\
\hline Italy & 1.99 & 22.59 & 8.79 & 3.54 & 22.92 & 15.45 & 0.28 & 22.64 & 1.25 & 2.11 \\
\hline Japan & -7.29 & 22.92 & -31.81 & -7.07 & 23.88 & -29.60 & -8.01 & 23.16 & -34.57 & 9.97 \\
\hline Netherlands & 7.35 & 16.64 & 44.18 & 8.30 & 17.29 & 48.02 & 6.18 & 16.76 & 36.87 & 1.84 \\
\hline Switzerland & 7.39 & 16.06 & 45.99 & 6.63 & 18.44 & 35.94 & 7.67 & 15.29 & 50.18 & 3.11 \\
\hline U.K. & 5.74 & 14.72 & 39.02 & 6.85 & 15.24 & 44.96 & 4.45 & 15.15 & 29.37 & 10.44 \\
\hline U.S.A. & 5.80 & 13.94 & 41.58 & 6.48 & 12.41 & 52.23 & 4.18 & 17.14 & 24.36 & 49.46 \\
\hline
\end{tabular}

In the SIM, the beta coefficients of the countries are not very far from 1 and range from 0.81 to 1.16 , which shows that the returns of the country and world indices have a tendency to move together. This reflects the significant level of common variance between the returns of the country and world market indices. However, the greater variability of the significant beta coefficients obtained from the two-and three-factorial models implies that the chosen allocation policies have varying diversifying effects for global equity diversification.

In Table 3A, the results of the SIM show that the most powerful determinant for the total variance of the equity returns of the developed markets is the global market-specific risk, which is a possible future detriment for global equity diversification. We see that more than half of the major developed markets have a GSRF, or $\mathrm{R}^{2}$, of greater than 50 percent, which point out the continued integration of the major developed markets and verify the previous findings (i.e. Goetzmann, et al. (2005), Hu (2006), Bekaert, et al. (2007 and Sener (2008)). In these markets, the average GSRF is about 53 percent, and there is 47 percent of room for the country-specific risk, or more broadly for the idiosyncratic or diversifiable risk, component.

Those results have noteworthy implications for global diversification and pricing. First, and most 
important, almost half of the total risk can be reduced by global diversification and the benefits of global equity diversification continue. Second, in the major developed markets, country indices are most likely getting priced in the global setting more than in the local setting. Global systematic risk has now a greater influence on the expected returns of the country indices. This verifies the findings of Huang (2007) whose asset pricing tests suggest that large-cap stocks of developed countries are priced globally and financial integration has deepened in recent years. Third, region and country allocation policies still need to be seriously considered while dealing with global equity diversification.

Table 3A: Single-Factor and Two-Factor Regression Models (1989-2007)

\begin{tabular}{|c|c|c|c|c|c|c|c|c|}
\hline \multicolumn{4}{|c|}{ Single-Factor Model } & \multicolumn{5}{|c|}{ Two-Factor Model } \\
\hline Country & $\mathrm{a}$ & bw & $A d j-R^{2}$ & Country & $\mathrm{a}$ & bw & br & $\operatorname{Adj}-R^{2}$ \\
\hline Australia & $\begin{array}{l}0.004 \\
(1.62)\end{array}$ & $\begin{array}{c}0.81 \\
(12.58)^{*}\end{array}$ & $\begin{array}{c}0.43 \\
(158.16)^{*}\end{array}$ & Australia & $\begin{array}{c}0.005 \\
(1.84)^{*}\end{array}$ & $\begin{array}{c}0.70 \\
(7.28)^{*}\end{array}$ & $\begin{array}{c}0.09 \\
(1.50)\end{array}$ & $\begin{array}{c}0.43 \\
(80.69)^{*}\end{array}$ \\
\hline Belgium & $\begin{array}{c}0.004 \\
(1.67)^{* * *}\end{array}$ & $\begin{array}{c}0.84 \\
(13.72)^{*} \\
\end{array}$ & $\begin{array}{c}0.47 \\
(188.35)^{*}\end{array}$ & Belgium & $\begin{array}{l}0.002 \\
(0.80) \\
\end{array}$ & $\begin{array}{c}-0.15 \\
(-1.44)^{*}\end{array}$ & $\begin{array}{c}1.03 \\
(10.76) *\end{array}$ & $\begin{array}{c}0.66 \\
(203.10)^{*} \\
\end{array}$ \\
\hline Canada & $\begin{array}{l}0.001 \\
(0.35) \\
\end{array}$ & $\begin{array}{c}0.96 \\
(17.05)^{*} \\
\end{array}$ & $\begin{array}{c}0.58 \\
(290.63)^{*}\end{array}$ & Canada & $\begin{array}{l}-0.001 \\
(-0.25) \\
\end{array}$ & $\begin{array}{c}0.37 \\
(3.25) * \\
\end{array}$ & $\begin{array}{c}0.65 \\
(5.74) * \\
\end{array}$ & $\begin{array}{c}0.63 \\
(183.72)^{*} \\
\end{array}$ \\
\hline France & $\begin{array}{l}0.002 \\
(0.99)\end{array}$ & $\begin{array}{c}1.02 \\
(18.97)^{*}\end{array}$ & $\begin{array}{c}0.63 \\
(359.79)^{*}\end{array}$ & France & $\begin{array}{l}-0.000 \\
(-0.33)\end{array}$ & $\begin{array}{l}-0.038 \\
(-0.48)\end{array}$ & $\begin{array}{c}1.09 \\
(15.23)^{*}\end{array}$ & $\begin{array}{c}0.82 \\
(492.72)^{*}\end{array}$ \\
\hline Germany & $\begin{array}{l}0.001 \\
(0.38) \\
\end{array}$ & $\begin{array}{c}1.16 \\
(17.02)^{*} \\
\end{array}$ & $\begin{array}{c}0.58 \\
(289.77)^{*} \\
\end{array}$ & Germany & $\begin{array}{l}-0.002 \\
(-1.17) \\
\end{array}$ & $\begin{array}{c}-0.16 \\
(-1.11) \\
\end{array}$ & $\begin{array}{c}1.37 \\
(14.79) * \\
\end{array}$ & $\begin{array}{c}0.79 \\
(403.65)^{*} \\
\end{array}$ \\
\hline Hong Kong & $\begin{array}{l}0.004 \\
(1.06) \\
\end{array}$ & $\begin{array}{c}1.11 \\
(10.81)^{*} \\
\end{array}$ & $\begin{array}{c}0.35 \\
(116.94)^{*} \\
\end{array}$ & Hong Kong & $\begin{array}{l}0.005 \\
(0.28) \\
\end{array}$ & $\begin{array}{c}1.07 \\
(6.93)^{*} \\
\end{array}$ & $\begin{array}{c}0.04 \\
(0.35) \\
\end{array}$ & $\begin{array}{c}0.35 \\
(58.29)^{*} \\
\end{array}$ \\
\hline Italy & $\begin{array}{l}0.000 \\
(0.03) \\
\end{array}$ & $\begin{array}{c}0.94 \\
(10.23)^{*}\end{array}$ & $\begin{array}{c}0.33 \\
(104.71)^{*}\end{array}$ & Italy & $\begin{array}{l}-0.002 \\
(-0.62) \\
\end{array}$ & $\begin{array}{c}0.03 \\
(0.18) \\
\end{array}$ & $\begin{array}{c}0.94 \\
(5.66) *\end{array}$ & $\begin{array}{c}0.41 \\
(76.06)^{*}\end{array}$ \\
\hline Japan & $\begin{array}{c}-0.008 \\
(-2.43) * * \\
\end{array}$ & $\begin{array}{c}1.09 \\
(12.73)^{*} \\
\end{array}$ & $\begin{array}{c}0.43 \\
(162.12)^{*}\end{array}$ & Japan & $\begin{array}{l}-0.001 \\
(-0.92) \\
\end{array}$ & $\begin{array}{c}-0.27 \\
(-9.33)^{*}\end{array}$ & $\begin{array}{c}1.21 \\
(63.68) *\end{array}$ & $\begin{array}{c}0.97 \\
(3666.44)^{*}\end{array}$ \\
\hline Netherlands & $\begin{array}{c}0.003 \\
(1.67) * * *\end{array}$ & $\begin{array}{c}0.97 \\
(19.97)^{*}\end{array}$ & $\begin{array}{c}0.65 \\
(298.64) *\end{array}$ & Netherlands & $\begin{array}{l}0.001 \\
(0.70)\end{array}$ & $\begin{array}{c}0.04 \\
(0.53)\end{array}$ & $\begin{array}{c}0.97 \\
(14.43)^{*}\end{array}$ & $\begin{array}{c}0.82 \\
(499.36)^{*}\end{array}$ \\
\hline Switzerland & $\begin{array}{c}0.004 \\
(1.69) * * *\end{array}$ & $\begin{array}{c}0.84 \\
(15.87)^{*} \\
\end{array}$ & $\begin{array}{c}0.52 \\
(227.13)^{*}\end{array}$ & Switzerland & $\begin{array}{l}0.002 \\
(0.70) \\
\end{array}$ & $\begin{array}{c}0.06 \\
(0.57) \\
\end{array}$ & $\begin{array}{c}0.81 \\
(8.74) *\end{array}$ & $\begin{array}{c}0.64 \\
(192.42)^{*} \\
\end{array}$ \\
\hline U.K. & $\begin{array}{l}0.002 \\
(1.27) \\
\end{array}$ & $\begin{array}{c}0.86 \\
(19.97)^{*} \\
\end{array}$ & $\begin{array}{c}0.65 \\
(398.72)^{*} \\
\end{array}$ & U.K. & $\begin{array}{l}0.000 \\
(0.01) \\
\end{array}$ & $\begin{array}{c}-0.02 \\
(-0.30) \\
\end{array}$ & $\begin{array}{c}0.91 \\
(16.43)^{*} \\
\end{array}$ & $\begin{array}{c}0.85 \\
(588.48)^{*} \\
\end{array}$ \\
\hline U.S.A. & $\begin{array}{l}0.002 \\
(1.57) \\
\end{array}$ & $\begin{array}{c}0.89 \\
(27.66)^{*}\end{array}$ & $\begin{array}{c}0.78 \\
(764.96)^{*}\end{array}$ & U.S.A. & $\begin{array}{l}-0.000 \\
(-0.07) \\
\end{array}$ & $\begin{array}{c}-0.02 \\
(-3.31)^{*}\end{array}$ & $\begin{array}{c}1.02 \\
(185.8)^{*}\end{array}$ & $\begin{array}{c}0.99 \\
(80215.21)^{*}\end{array}$ \\
\hline
\end{tabular}

$*, * *$, and $* * *$ denote significance levels of $1 \%, 5 \%$, and $10 \%$ respectively for $\mathrm{t}$ and $\mathrm{F}$ tests.

In Table 4, all (adjusted) coefficients of determination, or $\mathrm{R}^{2} \mathrm{~s}$, and the incremental contributions of the twoand three-factor models are summarized as risk fractions. In this way, it is easier to see the explanatory power of the region and value-growth allocation policies to the global returns and risks. In this table, a remarkable observation is that the region allocation explains on the average up to 54 percent (Japan) of the total variance of a country return, while the value-growth allocation contributes up to a maximum of 3.5 percent (Canada). The average contribution levels of the region and value-growth allocations are 17 percent and 0.62 percent respectively. Our estimate of 17 percent for the contribution of the regional allocation is very close to the finding of 15.5 percent of the study of Dijk and Keijzer (2004)). Similar to the results of the previously mentioned regional studies, we conclude that the region allocation policy is a powerful diversifying strategy. A striking result of the two-factor model is that the combined global and regional systematic risk can explain 63 to 100 percent of the total variance of country equity returns, if Australia, Hong Kong and Italy are ignored. When the diversifiable or country-specific risk component of the SIM is broken up, the country specific-risk fraction of the two-factor model may get quite smaller due to the dominant regional effect, particularly in the most efficient and developed markets such as U.S.A., U.K. and Japan. The country specific-risk will be more explanatory in the remaining developed markets that have lower degrees of 
market maturity.

Table 3B: Three-Factor Regression Model (1989-2007)

\begin{tabular}{|l|c|c|c|c|c|}
\hline \multicolumn{7}{|c|}{ Three-Factor Model } \\
\hline Country & $\mathrm{a}$ & $\mathrm{bw}$ & $\mathrm{br}$ & $\mathrm{bv}$ & Adj-R $^{2}$ \\
\hline \multirow{2}{*}{ Australia } & $\begin{array}{c}0.004 \\
(1.69)^{* * *}\end{array}$ & $\begin{array}{c}0.69 \\
(7.23)^{*}\end{array}$ & $\begin{array}{c}0.09 \\
(1.48)\end{array}$ & $\begin{array}{c}-0.31 \\
(-2.23)^{* *}\end{array}$ & $\begin{array}{c}0.44 \\
(56.47)^{*}\end{array}$ \\
\hline \multirow{2}{*}{ Belgium } & 0.002 & -0.14 & 1.01 & -0.14 & 0.66 \\
& $(0.78)$ & $(-1.39)$ & $(10.49)^{*}$ & $(-1.41)$ & $(136.71)^{*}$ \\
\hline \multirow{2}{*}{ Canada } & -0.001 & 0.35 & 0.61 & -0.38 & 0.67 \\
& $(-0.59)$ & $(3.21)^{*}$ & $(5.61)^{*}$ & $(-4.82)^{*}$ & $(143.2)^{*}$ \\
\hline \multirow{2}{*}{ France } & -0.0004 & -0.04 & 1.09 & 0.01 & 0.82 \\
& $(-0.32)$ & $(-0.47)$ & $(15.10)^{*}$ & $(0.10)$ & $(326.95)^{*}$ \\
\hline \multirow{2}{*}{ Germany } & -0.002 & -0.18 & 1.35 & -0.25 & 0.90 \\
& $(-1.22)$ & $(-1.84)^{* *}$ & $(14.87)^{*}$ & $(-3.07)^{*}$ & $(283.03)^{*}$ \\
\hline \multirow{2}{*}{ Hong Kong } & 0.004 & 1.13 & 0.008 & 0.13 & 0.35 \\
& $(1.05)$ & $(5.15)^{*}$ & $(0.04)$ & $(0.90)$ & $(39.0)^{*}$ \\
\hline \multirow{2}{*}{ Italy } & -0.002 & 0.05 & 0.93 & 0.197 & 0.41 \\
& $(-0.57)$ & $(0.25)$ & $(5.59)^{*}$ & $(1.07)$ & $(51.12)^{*}$ \\
\hline \multirow{2}{*}{ Japan } & -0.001 & -0.27 & 1.21 & -0.005 & 0.97 \\
& $(-0.93)$ & $(-9.14)^{*}$ & $(62.4)^{*}$ & $(-0.17)$ & $(2433.01)^{*}$ \\
\hline \multirow{2}{*}{ Netherlands } & 0.001 & 0.05 & 0.96 & 0.17 & 0.83 \\
& $(0.93)$ & $(0.67)$ & $(14.46)^{*}$ & $(2.53)^{* *}$ & $(343.56)^{*}$ \\
\hline \multirow{2}{*}{ Switzerland } & 0.003 & 0.06 & 0.77 & 0.19 & 0.65 \\
& $(1.42)$ & $(0.6)$ & $(8.45)^{*}$ & $(2.82)^{*}$ & $(135.15)^{*}$ \\
\hline \multirow{2}{*}{ U.K. } & 0.0002 & -0.02 & 0.91 & 0.13 & 0.85 \\
& $(0.16)$ & $(-0.27)$ & $(16.66)^{*}$ & $(2.37)^{* *}$ & $(402.82)^{*}$ \\
\hline \multirow{2}{*}{ (-0.000 } & -0.02 & 1.02 & -0.002 & 0.999 \\
$(-0.07)$ & $(-3.22)^{*}$ & $(174.99)^{*}$ & $(-0.64)$ & $(53276.79)^{*}$ \\
\hline
\end{tabular}

$*, * *$, and $* * *$ denote significance levels of $1 \%, 5 \%$, and $10 \%$ respectively for $\mathrm{t}$ and $\mathrm{F}$ tests.

Further, verifying the findings of Pozen and Fleishman (2005) as well as Phalippou (2008), the results of the three-factor model indicate that the value-growth allocation may not be a significant determinant for global equity diversification. In the three-factor model, its incremental contribution is negligible, ranging from 0 to 1 percent. We should also keep in mind that the methodology and/or sample used may be some of the explanation for the puzzling diversification power of the value-growth allocation policy.

Finally, an analysis of Figure 1 emphases the fact that the values of the (adjusted) coefficient of determination, $\mathrm{R}^{2}$, for the twelve countries are quite different from each other in the SIM versus the two-factor model, reflecting the substantial contribution of the regional allocation policy. However, the coefficients of the twofactor and three- factor models almost coincide with each other, showing that the additional contribution from the value-growth allocation is not significant for the sample period.

Table 4: Adj. $\mathbf{R}^{2}$ s and Their Increments in Two-and-Three Factor Regression Models (1989-2007) 


\begin{tabular}{|l|c|c|c|c|c|}
\hline \multirow{2}{*}{ Country } & \multicolumn{3}{|c|}{ Adjusted R Square (\%) } & \multicolumn{2}{c|}{ Increments (\%) } \\
\cline { 2 - 6 } & SIM & Two-Factor & $\begin{array}{c}\text { Three- } \\
\text { Factor }\end{array}$ & $\begin{array}{c}\text { Second } \\
\text { Factor }\end{array}$ & $\begin{array}{c}\text { Third } \\
\text { Factor }\end{array}$ \\
\hline Australia & 42.57 & 42.91 & 43.98 & 0.34 & 1.07 \\
\hline Belgium & 46.91 & 65.60 & 65.76 & 18.69 & 0.16 \\
\hline Canada & 57.74 & 63.29 & 66.80 & 5.55 & 3.51 \\
\hline France & 62.86 & 82.27 & 82.18 & 19.41 & -0.09 \\
\hline Germany & 57.67 & 79.16 & 89.96 & 21.49 & 0.80 \\
\hline Hong Kong & 35.35 & 35.08 & 34.99 & -0.27 & -0.09 \\
\hline Italy & 32.85 & 41.46 & 41.50 & 8.61 & 0.04 \\
\hline Japan & 43.18 & 97.19 & 97.18 & 54.01 & -0.01 \\
\hline Netherlands & 65.23 & 82.46 & 82.90 & 17.23 & 0.44 \\
\hline Switzerland & 51.61 & 64.36 & 65.50 & 12.75 & 1.14 \\
\hline U.K. & 65.23 & 84.71 & 85.04 & 19.48 & 0.33 \\
\hline U.S.A. & 78.28 & 99.87 & 99.99 & 21.59 & 0.12 \\
\hline
\end{tabular}

Figure 1: Graphical Illustration of the Adj. $\mathbf{R}^{2}$ s of the Three Regression Models

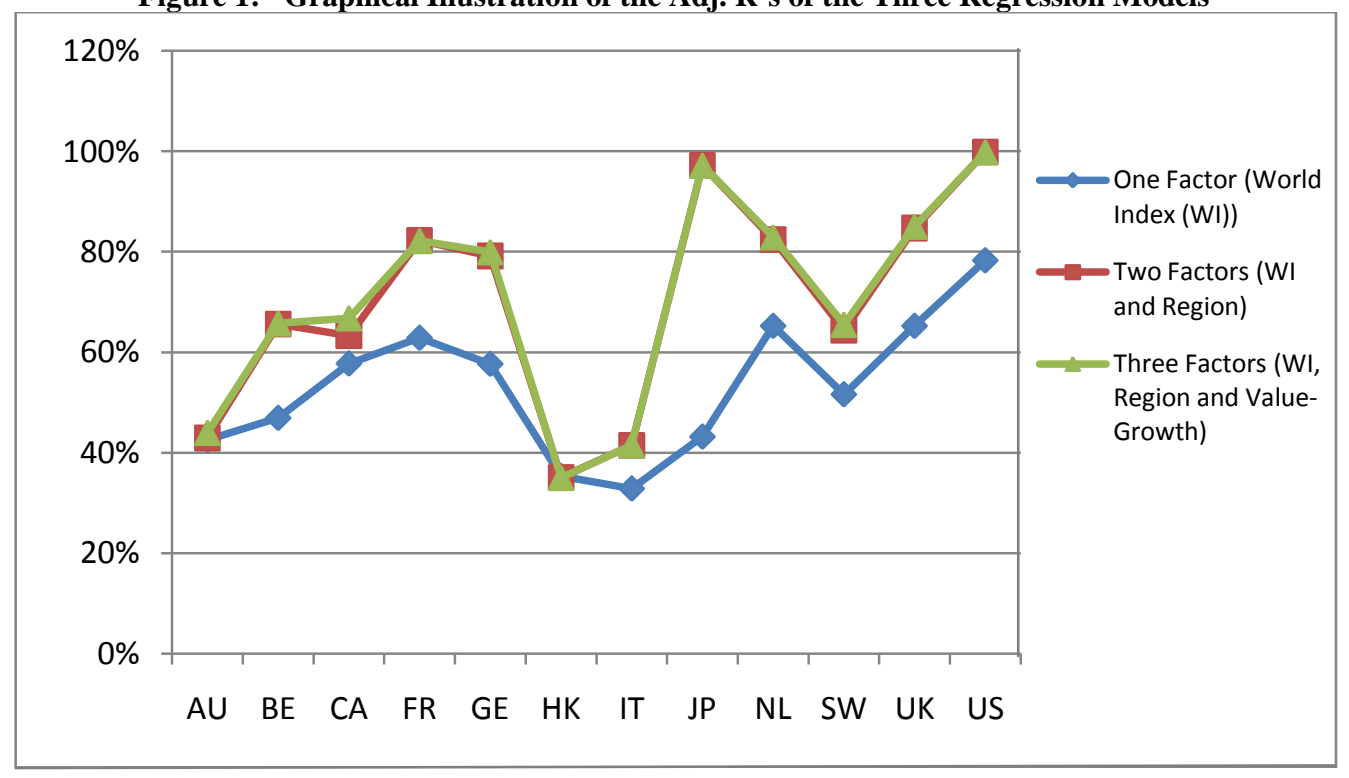

\section{SUMMARY AND CONCLUSIONS}

We have presented an analysis of the relative importance of the geographical (global, regional and national) allocation policies, as well as the value-growth allocation policy, by using long time-series data and a sample of twelve major developed markets. This analysis provides some empirical information that may be helpful for the global equity portfolio managers or international investors. It points out the increased importance of the global market-specific risk and the continued relative significance of the regional risk, while indicating the existence of some country effects at variable degrees.

The equity market integration process continues in major developed markets. The rather high systematic risk fractions, or $\mathrm{R}^{2} \mathrm{~s}$, of the SIM for the developed markets are the local manifestations of financial integration for 
the past two decades. Another finding of the study refers to international asset pricing and implies that expected returns in major developed equity markets are getting priced in the global setting more than in the national setting.

Nonetheless, about 42 percent of the major developed markets still have a systematic risk fraction, or $\mathrm{R}^{2}$, of less than 50 percent. Although the global market-specific risk is gaining dominance, there is still enough space for the explanatory power of region and country allocation policies and they are important for the efficient global equity diversification. If the explanatory power of the region allocation policy is added to the global market-specific risk, the two-factor model explains, on the average, 70 percent of the total variance of the country equity returns in the major developed markets. We see that region allocation policy makes very significant contribution and may even dominate the effect of the global market-specific risk in some cases (i.e. Japan). Finally, the three-factor model suggests that neglecting the value-growth allocation policy in the diversification strategy would be tolerable.

In brief, we confirm the conclusion of the previous literature that developed markets are gradually integrating and not fully integrated yet. In fact, diversification across regions provides very significant risk reduction for global equity diversification, and it may reduce the effect of the country-specific risk substantially. On the contrary, we conclude that the value-growth allocation policy can be insignificant. This article provides some empirical evidence particularly for those portfolio managers whose global equity allocation strategies presume that global equity markets somehow remain segmented.

\section{ACKNOWLEDGEMENT}

For assistance in calculations, we would like to thank Chien-Wen Hsiao for his hard work.

\section{ENDNOTES}

${ }^{1}$ This is a simplified basic assumption of those studies that do not deal with currency fluctuations (e.g. Fama and French (1998)).

${ }^{2}$ Although it is common in literature to assume that the idiosyncratic or diversifiable risk component of the SIM reflects broadly the country-specific risk, in fact it includes the marginal effects of all non-specified factors.

\section{AUTHOR INFORMATION}

Dr. Tulin Sener holds an M.A. and a Ph.D. from Claremont Graduate University. She has significant investment and development banking experience. Dr. Sener has published extensively on global equity investing, currency hedging, emerging markets, international capital markets, effects of inflation on financing and investment decisions and investment project appraisal. Dr. Sener has been the recipient of various well-known international grants as well as many teaching and research awards. senert@ newpaltz.edu.

Dr. Paul Berhanu Girma received his Ph. D from Rensselaer Polytechnic Institute in 1994. He is Associate Professor of Finance at the State University of New York at New Paltz. girmap@ newpaltz.edu.

\section{REFERENCES}

1. Bekaert, Geert, Campbell R. Harvey, Christian Lundblad and Stephan Siegel, Global Growth Opportunities and Market Integration, The Journal of Finance, Vol. 62, No. 3, pp. 1081-1137, 2007.

2. Brooks, Robin and Marco D. Negro, Country versus Region Effects in International Stock Returns, The Journal of Portfolio Management, Vol. 31, No. 4, pp. 67-72, 2005.

3. Campa, Jose M. and Nuno Fernandes, Sources of Gains from Individual Portfolio Diversification, Journal of Empirical Finance, Vol. 13 (On-line), pp. 417-443, 2006.

4. Dijk, Ronald V. and Tjeert Keijzer, Region, Sector and Style Selection in Global Equity Markets, Journal of Asset Management, Vol. 4, No. 5, pp. 293-307, 2004.

5. Fama, Eugene F. and Kenneth R. French, Value versus Growth: The International Evidence, The Journal of Finance, Vol. 53, No. 6, pp.1975-1999, 1998. 
6. French, Joseph J., Empirical Determinants of US Equity Flows to Developed Countries: Does Valuation Matter? Journal of International Finance and Economics, Vol. 8, No. 3, pp. 56-66, 2008.

7. Goetzmann, William N., Lingfeng Li and K. Geert Rouwenhorst, Long Term Global Market Correlations, Journal of Business, Vol. 78, No. 1, pp. 1-38, 2005.

8. Griffin, John M. and G. Andrew Karolyi, Another Look at the Industrial Structure of Markets for International Diversification Strategies, Journal of Financial Economics, Vol.50, No.3, pp. 351-373, 1998.

9. Heston, Steven L., and K. Geert Rouwenhorst, Industry and Country Effects in International Stock Returns, Journal of Portfolio Management, Vol. 21, No. 3, pp. 53-58, 1995.

10. Huang, Wei, Financial Integration and the Price of World Covariance Risk: Large- vs. Small-Cap Stocks, Journal of International Money and Finance, Vol. 26 (On-line), pp. 1311-1337, 2007.

11. Hu, Ou, Common and Country-Specific Components in National Stock Prices, Journal of Multinational Financial Management, Vol. 16 (On-line), pp. 509-519, 2006.

12. L'Her, Jean F., Omar Sy, and Mohammad Y. Tnani, Country, Industry and Risk Factor Loadings in Portfolio Management, The Journal of Portfolio Management, Vol. 28, No. 4, pp.70-79, 2002.

13. Naranjo, Andy and Burt Porter, Risk Factor and Industry Effects in the Cross-Country Comovement of Momentum Returns, Journal of International Money and Finance, Vol. 30 (On-line), pp. 1-25, 2009.

14. Phalippou, Ludovic, Where is the Value Premium? Financial Analysts Journal, Vol. 64, No. 2, pp. 41-48. 2008.

15. Pozen, Robert C. and Brett A. Fleishman, An Alternative Approach to International Investing, The Journal of Portfolio Management, Vol. 31, No. 3, pp. 19-26,.2005.

16. Puchkov, Anton V., Dan Stefek and Mark Davis, Sources of Return in Global Investing, The Journal of Portfolio Management, Vol. 31, No. 2, pp. 12-21, 2005.

17. Qian, Edward, Eric H. Sorenson, and Ronald Hua, Global Value Investing Delivers Diversification: a Multistrategy Perspective, The Journal of Portfolio Management, Vol. 35, No.2, pp. 42-49, 2009.

18. Sener, Tulin and Hadi Salavitabar Region and Industry Effects on the Equity Returns of Emerging Markets, Managerial Finance, Vol. 30, No. 3, pp. 17-27, 2004.

19. Measurement of the Power of Global Equity Diversification, Journal of International Finance and Economics, Vol. 8, No.1, pp. 98-110, 2008.

20. Sinquefield, Rex A., Where are the Gains from International Diversification? Financial Analysts Journal, Vol. 52, No. 10, pp. 8-14, 1996.

21. Soriano, Pilar and Francisco Climent, Region vs. Industry Effects and Volatility Transmission, Financial Analysts Journal, Vol. 62, No. 6, pp. 52-64, 2006.

22. Stultz, Rene M., The Limits of Financial Globalization, The Journal of Finance, Vol. 60, No. 4, pp. 15951638, 2005.

23. Vardharaj, Raman and Frank J. Fabozzi, Sector, Style, Region: Explaining Stock Allocation Performance, Financial Analysts Journal, Vol. 63, No. 3, pp. 59-70, 2007.

24. Wang, Chaug-Jung, Chien-Hui Lee, and Bwo-Nung Huang, An Analysis of Industry and Country Effects in Global Stock Returns: Evidence from Asian Countries and the US, Quarterly Review of Economics and Finance, Vol. 43 No. 3, pp. 560-577, 2003. 